\title{
Social capital, tiered entrepreneurship training, and agrotourism development model of Kampung Salak Bojonegoro
}

\author{
Noviaty Kresna Darmasetiawan \\ University of Surabaya, Surabaya, Indonesia
}

\begin{abstract}
This which was related to social capital in collaboration for the development of an industrial cluster, in which the concept of agropolitan area development inclines on a micro and local scale. The type of research used was qualitative research. The results of the current study were (1) Agropolitan Area Development Model which is inclined on micro and local scale, which is suitable with the social condition and local potency is empowering people to utilize its potential to increase value; (2) The spirit of entrepreneurship is a social capital to support the people for growing into Agribusiness of Kampung Salak through three things, namely salak agribusiness that has been improved in quality, utilization of living environment and daily, and growth of small micro enterprise (SMEs) in the field of processed salak products and salak agro-tourism support system; (3) Tiered Entrepreneurship Training shall increase the competence of business actors in Kampung Salak in accordance with the level of business owned.
\end{abstract}

Keywords: Social Capital, Collaboration, Tiered Entrepreneurship Training, Agro-tourism Development

\section{INTRODUCTION}

Wedi Village and Tanjungharjo Village at Kapas District in Bojonegoro Regency has the potential to be Thorny Palm (Salak Fruit) Wedi Agribusiness Centre. There is available salak plantation area for 75 ha and production of salak in 2013 reaching 19,511 quintals.

Thorny Palm of Wedi (Wedi's Salak fruit) is a hereditary heritage, growing in almost every yard belonging to the community of Wedi Village and Tanjungharjo Village at Kapas District in Bojonegoro Regency. However, Salak Wedi has many obstacles, namely in terms of lack of taste and quality, but the people of Bojonegoro have an entrepreneurial spirit. It is a social capital to support the development of Bojonegoro as Agropolitan Area.

Bourdieu \& Wacquant (1992), proposed the definition of social capital as a number of resources, both actual and virtual, that develop because of having a long-lasting network in institutionalized relationships based on mutual knowledge and recognition. Meanwhile, according to Colemen (1988), social capital consists of two elements, namely various aspects of social structure, and how social structures can facilitate certain actions of actors in the so- cial structure. Furthermore Niu et al. (2008), Niu (2009) and Darmasetiawan et al. (2013 advocated that social capital can form the basis of collaboration between organizations within an industry cluster, and change the current paradigm that says competitive strategy is the only strategy that can be applied in business, a collaborative strategy, which can facilitate the development of a business. Social capital can provide benefits to group members, such as information, influence, and control (Sparrowe et al. 2001). The existence of information, influence, and control is needed to build and develop agropolitan area. The development of the agropolitan areas undertaken focuses on the growth of micro and local enterprises, rather than macro growth, in line with the research of Anton et al. (2015), on how SMEs in Indonesia can be more competitive.

The growth of the micro and local business can be driven by the entrepreneurial spirit owned by the community. The spirit of entrepreneurship is the entrepreneurial spirit to work hard by devoting all the capabilities it has, so as to run and achieve business goals optimally (Supriyanto 2012).

Training of tiered entrepreneurship was conducted as an effort to form a new micro business and also increase the competence of business actors at 
middle and advanced levels. Training is a short-term educational process that uses systematic and organized procedures (Sikula 2016) to improve knowledge and skills (Mathis \& Jackson 2002).

The research questions proposed in this research are: (1) How is the model of Agropolitan Area development that is inclined on the micro and local scale, and in accordance with the social condition and local potency contained in Wedi and Tanjungharjo Village at Kapas District in Bojonegoro Regency?; (2) How can entrepreneurship spirit be a social capital to support agro-tourism of Salak Village in Bojonegoro?; (3) How does Tiered Entrepreneurship Training support the agrotourism development model of Salak Village in Bojonegoro?

\section{RESEARCH METHODS}

The research was a qualitative descriptive research, where the researcher knows the position at the time of data collection in the field, and become the data interpreter (Moleong 2011).

Sampling technique used in this research was purposive sampling, which is sampling technique from a data source with a certain consideration. (Sugiyono 2013).

Data collection techniques used in-depth interviews, the researchers looking for data by interviewing in depth all the relevant informants consisting of business actors in "Kampung Salak" Wedi Village and Tanjungharjo Village, which related to salak seller, business actor in agro field, and business of processed products. The number of informants is 8 people. In-depth interviews conducted, equipped with observations, namely data collection techniques by observing the attitude of research subjects.

Data collection techniques used in-depth interviews, the researchers looking for data by interviewing in depth all the relevant informants consisting of business actors in "Kampung Salak" Wedi Village and Tanjungharjo Village, which related to salak seller, business actor in the agro field, and business of processed products. The number of informants was 8 people. In-depth interviews conducted, equipped with observations, namely data collection techniques by observing the attitude of research subjects.

Data analysis techniques used (1) data reduction, data collected from the field in the form of results indepth interview and observation, recorded in detail and thorough, then summarized, selected key points, focus on the things that are important and sought the theme and the pattern. After that was done, (2) display data after the data were reduced, then the next step was to perform the presentation of data. The presentation was done in the form of a brief description, making the chart, the relationship between categories, flowchart, in this study used narrative text. And the last step was (3) conclusion drawing/ verification which was the drawing of conclusions and verification.

\section{RESULTS AND DISCUSSIONS}

The village of Tanjungharjo and Wedi village have different social characteristics, although these two villages are very close together, and both have an entrepreneurial spirit.

The people of Tanjungharjo Village tend to wait for each other at the time of entrepreneurship, but the village head and some structural villages are very active and able to become the pioneer of Tanjungharjo village community to start entrepreneurship.

Salak processed products produced by the community of Tanjungharjo Village are mostly in the form of wet cake products. Therefore, the right model as a model of Agropolitan area development that is inclined on the micro and local scale, and in accordance with the social conditions and local potentials located in the Village Tanjungharjo, is the village structural and agro-tourism movers who have the capital, took the initiative to open a kind of cafe, catering business, and other business related to agrotourism of salak garden. The social structure of Tanjungharjo Village can involve surrounding communities to participate in selective and regulated businesses with a clear system.

In contrast, the Wedi community is almost entirely mutually active and supportive although the village head is not overly concerned. The people are competing to make processed products in packaging and manage the salak garden to become agrotourism that is ready to be marketed. Therefore, the right model for the development of the Agropolitan Area of "Kampung Salak" Wedi Village is to make the Wedi Village as the Village of Salak Wedi superior, where in addition to offline marketing also done online marketing, which is also a means of promotion for agrotourism of Salak Wedi.

The development model that is carried out in both Wedi and Tanjungharjo villages can be integrated with each other by using industrial cluster model of agropolitan area development. The cluster development model has proven to be effective in today's economic development, for example, Silicon Valley in the United States is very famous in the world. The industrial cluster deals with the attachment between businesses in a geographical location, which can be 
due to the location having a comparative advantage (Dunning 1988).

The model of agropolitan area development that uses the concept of an industrial cluster, involves community empowerment so that the community can increase the local potency of its area, its Salak, and its capability to be more able to create value for the business field related to Salak that has been done.

The spirit of entrepreneurship is a passion for entrepreneurship. The entrepreneurial spirit is very prominent, especially in the community of Wedi Village. Motto owned by the people of Wedi Village is "From Salak We Moved, from Wedi We Innovate". Its people are very responsive to change, especially those that bring progress to the village of Wedi. It can be a social capital to support agro-tourism development of Kampung Salak Bojonegoro, through the growth of community potential to become a new micro business entrepreneur in Salak Agrotourism, including salak agribusiness which has been improved in quality, utilization of living environment and its daily to be marketed as an object of agro tourism, and growth of small and medium enterprises (MSMEs) in the field of salak and salak agrotourism products such as souvenirs that indicate the existence of Agro tourism of Kampung Salak.

Increased competence of prospective micro business actors, as well as micro-entrepreneurs is done through tiered entrepreneurship training

The tiered entrepreneurship training is conducted in three levels, namely the basic level for new micro entrepreneurs, middle level for micro entrepreneurs who have been running their business but need improvement from various aspects of business, such as packaging improvement, more equipment using appropriate technology, and others, while the advanced level training for micro entrepreneurs who will further develop their business in order to have a wider turnover and market share.

Indonesia is a country with such a large area with a huge number of populations, but Indonesia only has 0.18 percent of its population as an entrepreneur. This shows that there is still a need to add new entrepreneurs in the future.

\section{CONCLUSIONS}

The From the above discussion it is concluded that (1) The model of Agropolitan Area Development that is inclined on the micro and local scale, which is in accordance with the condition of society and local potential is empowering the community to be able to utilize its potential to increase value; (2) The spirit of entrepreneurship is a social capital to support the community grow into Agro Business Actor of "Kampung Salak" through three things, namely salak agribusiness that has been improved its quality, the utilization of living environment and its daily to be marketed as an object of agro tourism, and the growth of micro small and medium enterprises (SMEs) in the field of processed salak products and Salak agro-tourism support system; (3) Training of Tiered Entrepreneurship provides increased competence of business actors in "Kampung Salak" in accordance with the level of business they owned.

\section{REFERENCES}

Anton, S.A., Muzakan, I., Muhammad, W.F., Sidiq, S.N.P. 2015. An Assessment of SME Competitiveness in Indonesia. Journal of Competitiveness 7(2): 60-74.

Bourdiau, P. \& Wacquant, L. 1992. An Invitation to Reflexive Sociology. Chicago: The University of Chicago Press.

Colemen, J.S. 1988. Social Capital in The Creation of Human Capital. American Journal of Sociology 94: S95-S120.

Darmasetiawan, N.K., M.I. Idrus, Eka A.T., \& Ubud S. 2013. Organizational Trust, Willingness to Share, Membership Involvement, and Knowledge Obtaining (Study on Health Industrial Cluster: PERSI, GP Farmasi, and Gakeslab Association in East Java. International Journal of Business and Management Tomorrow 3(1): 1113-14.

Dunning, J.H. 1988. The Eclectic Paradigm of International Production: A restatement and some possible extensions. Journal of International Business Studies 19(Spring).

Mathis, R., \& Jackson J. 2002. Manajemen Sumber Daya Manusia. Jakarta: Salemba empat

Moleong, L.J. 2011. Metode Penelitian Kualitatif. Bandung: Remaja Rosdakatya.

Niu, K.H. 2009. Organizational Trust and Knowledge Obtaining in Industrial Clusters, Journal of Knowledge Management. Emerald Group Publishing Limited 14(1): 2010.

Niu, K.H., Miles, G. \& Lee, C.S. 2008. Strategic Development of Network of Clusters: a Study of High Technology Regional Development and Global Competitiveness. Competitiveness Review 18(3): 176-91.

Sikula. 2016. Model Perencanaan SDM. http://manajemensdm.com/perencanaan-sdm/151/

Sparrowe, R.T., Liden, R.C., Wayne, S.J. \& M.L. Kraimer. 2001. Social Network and the Performance of Individuals and Groups. The Academy of Management Journal 44(2): 316-325.

Sugiyono. 2013. Metode Penelitian Kuantitatif, Kualitatif, Dan Kombinasi (Mixed Methods). Edisi Keempat. Bandung: Alfabeta.

Supriyanto. 2012. Available at: http://supriyantopris.blogspot.co.id/2012/04/konsep-semangatkewirausahaan.html 